\title{
Organic Apple Production in Two Humid Regions: Comparing Progress in Pest Management Strategies in Iowa and New Zealand
}

\author{
Kathleen Delate ${ }^{1}$ and Andrea McKern \\ Department of Horticulture, Iowa State University, 106 Horticulture Hall, Ames, IA 50011-1100 \\ Robert Turnbull \\ Department of Entomology, Iowa State University, 110 Insectary Hall, Ames, IA 50011-3140
}

James T.S. Walker, Richard Volz, Allan White, Vincent Bus, Dave Rogers, Lyn Cole, Natalie How, and Sarah Guernsey

The Horticulture and Food Research Institute of New Zealand, Ltd., Private Bag 1401, Havelock North, New Zealand Jason Johnston
The Horticulture and Food Research Institute of New Zealand, Ltd., Private Bag 92169, Auckland 1142, New Zealand

Additional index words. codling moth, controlled atmosphere, leafroller, woolly apple aphid, scab-resistant cultivars

\begin{abstract}
By 2003, organic apple [Malus sylvestris (L.) Mill var. domestica (Borkh.) Mansf.] production had increased to 5626 ha in the United States and to 2964 ha in New Zealand by 2002 . Common problems facing organic apple growers in the humid regions of New Zealand and the United States include effective management strategies for apple scab [Venturia inaequalis (Cooke)] and insect pests. Experiments conducted in Iowa in 2003-2004 demonstrated the effectiveness of a kaolin clay- and spinosad-based insecticide program in maintaining codling moth [Cydia pomonella (L.)] damage levels to less than 5\% in the scab-resistant cultivars Enterprise, Liberty, Redfree, and Gold Rush. Similar pest management systems have been developed in New Zealand to comply with export standards and quarantines. The use of codling moth granulosis virus and a spinosad-based insecticide have led to reduced pest pressure and to an increase in organic exports with a $41 \%$ premium price over conventional apples. However, an association between spinosad use and woolly apple aphid [Eriosoma lanigerum (Hausmann)] population increase was observed in organic orchard surveys in 2006. An alternative to spinosad applications, insect disinfestation through controlled atmosphere (CA) treatment, was investigated to control quarantined pests and to extend the storage potential of scab-resistant cultivars. A CA treatment of 9 weeks of $2 \% \mathrm{O}_{2}$ and $2 \% \mathrm{CO}_{2}$ at 0.5 ${ }^{\circ} \mathrm{C}$ was determined to maintain firmness ratings to export standards in $\mathrm{CA}$-stored, scab-resistant 'Pinkie' apples and to decrease internal ethylene concentration by $84 \%$ compared with apples stored in air. In addition, new scab-resistant cultivars with 'Pinkie' background under development in New Zealand show promise for organic production in humid regions. Few fruit quality differences were determined between 'Pinkie' fruits from integrated fruit production and organic production systems, although premium prices exist only for certified organic apples.
\end{abstract}

Experiencing a fivefold increase from 1997 to 2003 to 5626 ha in organic apple production in the United States (U.S. Department of Agriculture-Economic Research Service, 2003), organic apple growers have requested assistance from universities and research institutes to address key production and postharvest issues for their industry. Concerns for environmental health, food safety, and food quality have motivated consumer demand for organic products (Crawshaw, 1997; Organic Trade Association, 2005), and new organic pest and disease management strategies, improved orchard management practices, and marketing incentives, particularly in the European Union (EU), have increased the supply of organic apples (Weibel, 2001). Key issues for organic fruit growers include selection of cultivars that are traditionally developed (nongenetically modified) in compliance with U.S. Department of Agriculture-certified organic regulations (U.S. Department of Agriculture-

Mention of commercial brand names does not constitute an endorsement of any product by Iowa State University or cooperating agencies.

${ }^{1}$ To whom reprint requests should be addressed; e-mailkdelate@iastate.edu.
Agriculture Marketing Service, 2006) and that meet production area constraints and market demands. Insect pest and disease management, weed control, and plant nutrition are also important issues for organic apple growers (Ames and Kuepper, 2004; Swezey et al., 2000; Weibel, 2001). Management of apple scab disease (or black spot) requires intensive spray programs in humid regions (Tamm et al., 2004) or the use of scab-resistant cultivars (Bus et al., 2002; Delate et al., 2005). Challenges associated with scab-resistant cultivars include poor shipping potential (Brookfield, 1999) and poor eating quality of certain cultivars (Selby and White, 1993).

The role of beneficial insects in providing biological control of fruit crop pests has been reported worldwide (Solomon et al., 2000; Wearing et al., 1995a), but when these options fail to provide adequate control, least toxic, organic-compliant insecticides are used (Swezey et al., 2000). However, nontarget effects of some organic-compliant insecticides, such as mortality of beneficial insects and resurgence of secondary pests, are becoming key concerns in organic orchards.

The humid regions in New Zealand and in the United States share many common prob- lems in relation to organic apple production: acceptance and improvement of scab-resistant cultivars, more effective methods for managing specific insect pests, and methods to extend storage life in currently available scab-resistant cultivars. The objectives of this study were 1) to compare management systems in organic apple orchards in humid regions in New Zealand and in Iowa; 2) to evaluate differences in insect and disease development among scab-resistant cultivars in an organic orchard in a humid region of Iowa; 3) to evaluate tree performance and fruit quality, at harvest and after controlled atmosphere (CA) treatment, of New Zealand scab-resistant cultivars with potential for importation into the United States; 4) to determine the effect of a systems approach using pheromone technology on leafroller presence in organic apples in a humid region of New Zealand; and 5) to determine associations between a new organic-compliant insecticide in use in New Zealand and in the United States and nontarget effects on secondary pests and beneficial insects. Comparisons between the two countries' strategies and effectiveness of these strategies for future use in organic apple systems are considered. 


\section{ORGANIC APPLE PRODUCTION IN NEW ZEALAND}

New Zealand is a country of four million people with 1000 organic growers farming $\approx 46,000$ ha -2964 ha of which were used in organic apple production in 2002 (Statistics New Zealand, 2006). As a global food exporter, New Zealand's growth in organic foods is expected to exceed NZ\$500 million in 2006 (Seagor, 2006). This development occurred with minimal governmental support, in contrast to the EU organic sector (Campbell and Fairweather, 1998). Certified organic production of kiwifruit and apple crops has increased dramatically during the past decade and accounts for $71 \%$ of organic exports from New Zealand (Organic Products Exporters of New Zealand, 2006). Exports of organic apples reached 800,000 cartons in 2005. Since the initiation of the organic apple sector in New Zealand, key insect and disease pests have been managed using organically approved methods, such as S-based fungicides for scab and powdery mildew, and granulosis virus and mating disruption for codling moth (McArtney and Walker, 2004). In addition to codling moth, the most challenging apple insect pests in New Zealand are leafrollers and the bronze beetle [Eucolaspis brunnea (F.)] (Rogers et al., 2006). Leafrollers include the light-brown apple moth, Epiphyas postvittana (Walker) (LBAM), which can restrict fruit entry into parts of the United States if intercepted during preexport inspections. Lesser pests include the leaf-curling midge, mites, leafhoppers, mealybugs, and scale insects, which are generally managed by natural enemies (Wearing et al., 1994).

Centered around Hawke's Bay, on the southeastern coast of the North Island, New Zealand, is one of the highest concentrations of organic apple producers in the world, with about $25 \%$ of the apple growers there practicing organic techniques. Nationally, between $5 \%$ and $10 \%$ of the entire New Zealand apple crop is grown organicallythe fourth largest organic apple crop in the world. In a country driven by exports, New Zealand organic growers have developed a sophisticated systems approach to tackle insect and disease problems to produce highquality apples for export. Similar to midwestern Unites States organic apple growers, New Zealand growers must systematically manage several key pests, notably scab and codling moth. The weather conditions in Hawke's Bay, New Zealand (rainfall, $\approx 700 \mathrm{~mm} /$ year; summer maximum temperature, $25^{\circ} \mathrm{C}$; summer minimum temperature, $13.7^{\circ} \mathrm{C}$; winter maximum temperature, $14{ }^{\circ} \mathrm{C}$; and winter minimum temperature, $3.3{ }^{\circ} \mathrm{C}$ ) are favorable for apple scab infection. The use of scabresistant cultivars is not prevalent in the Hawke's Bay area because of putative management of apple scab with a sulfur/lime/ copper spraying regime, the reported poor shipping potential of scab-resistant cultivars (Brookfield, 1999), and poor eating quality of some scab-resistant cultivars (Selby and
White, 1993). Recently, however, a renewed focus on the negative impacts of sulfur on tree and human health (McArtney and Walker, 2004) has led to the development of scab-resistant cultivars that maintain shelf life throughout the export market chain.

In addition to common U.S. apple insect pests, the management of quarantined pests, such as woolly apple aphid (WAA) and light brown apple moth (LBAM), on fruit for export to overseas markets creates an additional burden for the New Zealand organic apple grower. Fruit containing WAA can be prevented from entering California, one of the most lucrative overseas markets (Wearing et al., 1994). The WAA is found in the state of Washington, but not in the midwestern United States and it affects yield to a lesser degree than codling moth, but proves to be a cosmetic pest, because it is difficult to remove from its secure location in the apple stem end.

Leafrollers are another pest that must be managed for export markets. For most organic growers, the leafroller complex found in their orchards: LBAM, brownheaded leafrollers (Ctenopseustis obliquana and $C$. hereana), and green-headed leafrollers (Planotortrix octo and P. excessana) are indistinguishable, but evidence of leafroller damage or larvae on fruit can restrict access to U.S. markets because of LBAM. A new sighting of LBAM in California in May 2007 (U.S. Department of Agriculture-Animal and Plant Health Inspection Service, 2007) may lift LBAM quarantine restrictions to California in the future, but other parts of the United States continue to restrict fruit with evidence of LBAM. Several tactics are used to limit the various insect pest populations, including planting flowering strips between tree rows to provide pollen and nectar to encourage parasitic wasps and predators of these pests. In addition, the combined use of pheromone monitoring traps and rigorous organic spray programs has been enacted to increase market access.

Beginning in 2000, New Zealand growers also reported significant bronze beetle damage in their organic blocks. A native insect found in forest trees, the bronze beetle had primarily been a minor pest on apples, managed by insecticides commonly used in integrated fruit production (IFP) programs. After larger blocks of organic apples were planted, however, bronze beetle populations began to increase within organic orchards and are now considered the most important pest in the organic apple sector. Because bronze beetle feeding scars can render an apple completely unmarketable, an estimated NZ \$16 million loss to the organic apple producers was anticipated in 2006 from bronze beetle damage. In 2006, some orchards were found to contain up to $80 \%$ bronze beetle-damaged fruit (Rogers et al., 2006). The insecticides commonly used in organic production (pyrethrum and neembased formulations) have not proved to be sufficiently efficacious against bronze beetle.

Special programs have been developed for LBAM management, including the use of pheromone-baited sticky traps to monitor leafroller populations in the orchard, Bacillus thuringiensis early in the season, Entrust (an organic insecticide released in 2003, developed from a soil-dwelling fungus, spinosad) later in the season, and a rigorous selection of noninfested apples at picking, field packing, and in the packinghouse line. Spinosad was hailed as a major breakthrough in organic fruit pest management when first introduced in 2003, but the effect of this insecticide on nontarget organisms, such as beneficial predators and parasitic wasps that attack WAA populations, has been reported by some growers. In $2005, \approx 50 \%$ of growers reported using three or more Entrust sprays per season. Postharvest strategies for leafroller management include CA storage (Jamieson et al., 1999; Waddell et al., 1990) using $2 \% \mathrm{O}_{2}$ and $2 \% \mathrm{CO}_{2}$ at temperatures of $0.5{ }^{\circ} \mathrm{C}$ for a minimum of 8 weeks.

Excellent organic apple yields have been obtained in New Zealand. Using 'Braeburn' as an example, in 2005, average yields were $58,941 \mathrm{~kg} \cdot \mathrm{ha}^{-1}$ in the Hawke's Bay area (Hughes, 2006). Conventional 'Braeburn' yields were $27 \%$ higher than organic, but there was a $41 \%$ higher premium price paid for organic 'Braeburn' apples, compensating for the lower yields. Organic 'Braeburn' apple fruit size has been generally smaller than conventional, with an average apple weight of $160 \mathrm{~g}$ compared with $176 \mathrm{~g}$ for conventional 'Braeburn'. Commonalities among the most successful organic orchards included improvements in canopy and crop management, possibly from greater tree-soil health inputs, including compost, solid, and foliar inputs (averaging NZ \$636 ha ${ }^{-1}$ ); foliar $\mathrm{N}$ levels averaging $2.4 \%$; the use of $2 \%$ lime sulfur and hand thinning (averaging NZ $\$ 6.33 /$ tree); fewer fungicides overall (total organic average sulfur rate, $60 \mathrm{~kg} \cdot \mathrm{ha}^{-1}$; and copper, $2.1 \mathrm{~kg} \cdot \mathrm{ha}^{-1}$ ), including less late-season sulfur applications and low scab infection at harvest; and more growers opting for CA storage (Hughes, 2006). Hughes et al. (2002) reported an average reduction in yield of $8 \%$ to $25 \%$ in New Zealand organic apple orchards compared with their conventional counterparts, depending upon the cultivar.

\section{ORGANIC APPLE PRODUCTION IN THE MIDWESTERN UNITED STATES}

The majority of U.S. organic apple production is in the semiarid region of Washington state (U.S. Department of Agriculture-Economic Research Service, 2003) because of low disease pressure there (Granatstein, 2004), but organic apple production is considered an important industry in the midwestern United States because of a longstanding tradition of apple production and consumption among midwesterners, and high numbers of organic producers in Iowa, Wisconsin, Michigan, and Minnesota (U.S. Department of Agriculture-Economic Research Service, 2003), which enables support networks. With 254 ha of organic apple production in the midwestern United States 
(U.S. Department of Agriculture-Economic Research Service, 2003), marketing outlets for organic produce include on-farm stores, local and regional farmers' markets, and health food-focused shops. Beginning in 1999, kaolin clay formulations that repel and irritate insect pests (Glenn et al., 1999) became increasingly important insecticides in organic apple orchards (Delate and Friedrich, 2004; Friedrich et al., 2003; Garcia et al., 2004). Surround WP (Engelhard Corp., Iselin, NJ) has been the most widely used formulation of this white-clay particle film. Insect recognition of host plants may also be deterred by this product, because plant hosts are "masked" by kaolin particle film. Surround kaolin clay has provided putative management of codling moth and other lepidopteran and coleopteran fruit pests in apple systems (Dufour, 2001; Friedrich et al., 2003; Knight et al., 2000; Puterka et al., 2000; Unruh et al., 2000), with reports of increased photosynthetic rate and fruit yield from kaolin applications (Glenn et al., 2003).

Integrated approaches are used in certified organic apple systems in the Midwest and humid regions of the United States to control the most destructive insect pests: codling moth, plum curculio [Conotrachelus nenuphar (Herbst)], oblique-banded leafroller [Choristoneura rosaceana (Harris)], oriental fruit moth [Grapholita molesta (Busck)], and apple maggot [Rhagoletis pomonella (Walsh)]. Multiple tactics in these regions have been reported: kaolin clay in managing several insect pests (Friedrich et al., 2003; Garcia et al., 2004), scab-resistant cultivars (Delate et al., 2005; Merwin et al., 2005), and understanding whole-orchard ecosystem dynamics, including rootstock selection (Whalon et al., 2005).

The main commonalities between midwestern United States and New Zealand organic apple production are scab disease and codling moth. The organic apple growers located in the arid western United States, and the drier regions of the South Island in New Zealand, have a substantial advantage over midwestern and eastern U.S. apple-growing regions as a result of lower disease pressure. With disease-resistant cultivars and rigorous pest management, organic apple growers in humid regions can effectively produce directly marketable fruit for the consumer who prefers locally produced, organic apples. The main difference between organic orchards in New Zealand and those in the Midwest, however, is the predominance of an export market focused on cultivars with a high susceptibility to scab.

\section{MATERIALS AND METHODS}

\section{Organic apple cultivar evaluation in the midwestern United States}

An experiment was conducted in 2003 and 2004 in Iowa to evaluate insect pest and disease load in four scab-resistant apple cultivars in a certified organic apple orchard (Delate et al., 2005). The objective of this on- farm demonstration was to compare apple cultivar susceptibility to plum curculio, codling moth, and apple diseases under an intensive organic spray program. Weather conditions during the growing season in Adel, IA, were similar to those in Hawke's Bay, New Zealand, where scab infection periods followed frequent summer rains. Fruit from 10 trees (7- to 10 years old) of each of four scab-resistant cultivars'Enterprise', 'Liberty', 'Gold Rush', and 'Redfree' —on dwarfing rootstock [Malling9 (M-9)] were sampled for insects, diseases, and fresh weight at harvest. The entire orchard was treated uniformly, per local organic practices, to avoid creating a refugium for insect pests and diseases in any untreated control blocks. Similar spray programs were used in 2003 and 2004. The 2003 program included Surround WP applied at $56 \mathrm{~kg} \cdot \mathrm{ha}^{-1}$ on 16,21 , and 29 May; $B$. thuringiensis (Dipel; Valent BioSciences Corp., Libertyville, IL) on 16, 21, and 29 May, 10 and 26 June, and 2 and 11 Aug. at $1.12 \mathrm{~kg} \cdot \mathrm{ha}^{-1}$; and Entrust (Dow AgroSciences LLC, Indianapolis, IN) was sprayed on 16 and 29 May, 10 June, and 2 and 11 Aug. at $146 \mathrm{~mL} \cdot \mathrm{ha}^{-1}$, and on 26 June at $292 \mathrm{~mL} \cdot \mathrm{ha}^{-1}$. No fungicides were applied. Harvest data included fresh weight of 20 apples per tree (200 per cultivar) and the percentage of apples damaged from codling moth and plum curculio feeding. Harvest periods during the course of the experiment included 'Redfree' harvested on 9 Aug., 'Liberty' on 26 Sept., 'Enterprise' on 4 Oct., and 'Gold Rush' on 20 Oct. All data were subjected to analysis of variance and mean separation (Fisher's PLSD test at $P \leq 0.05$ ) (SAS Institute, 2001).

\section{Evaluation of scab-resistant cultivars at harvest and under controlled atmosphere treatment}

One of the key strategies proposed for apple scab disease management in organic orchards is the development and use of scabresistant cultivars. To maintain the highvalue export market of the United States for New Zealand organic apples and to decrease $S$ use among organic orchardists, two approaches are underway at HortResearch, Ltd. (Hawke's Bay and Auckland, New Zealand): enhanced selection of scab-resistant cultivars and determining $\mathrm{CA}$ responses for these cultivars.

Harvest evaluation. Apples were evaluated from the HortResearch orchard in Havelock North, New Zealand, from February to May 2006. Fruit from two commercial scabresistant cultivars, 'Liberty' and 'Pinkie', and two unreleased scab-resistant selections with 'Pinkie' background, called Selection A (2-year-old trees) and Selection B (3-yearold trees), were compared with a scabsusceptible cultivar, 'Pacific Rose'. Subcomparisons occurred between Selection B (2-year-old trees) fruit on M-9 rootstock and on Geneva-202 (G-202) rootstock. Twenty apples/cultivar/rootstock were sampled weekly from February to March, and harvested when a random sample of less than or equal to six apples per week began to show a change in starch hydrolysis determined by the starch pattern index (SPI) (ENZAFRUIT, 2007).

Fruit were immediately weighed after harvest and evaluated for skin color (visual estimate of percent red blush). Fruit maturity and quality parameters measured included fruit firmness, total soluble solids, SPI, background skin color, titratable acidity (TA), and internal ethylene concentration (IEC). Fruit firmness was evaluated on peeled fruit using a Fruit Texture Analyzer (model GS14; Güss, South Africa) fitted with an 11.1-mm penetrometer probe (Effegi, Milan, Italy). The probe was driven into the flesh at $5 \mathrm{~mm} \cdot \mathrm{s}^{-1}$ to a depth of $9 \mathrm{~mm}$, and the maximum force was recorded as the firmness value. Two readings were made on opposite sides of the fruit where the peel was removed. Total soluble solids were determined by placing an aliquot of the juice released during firmness measurements onto a digital refractometer (model PAL-1; Atago, Japan). Starch pattern index was determined by covering the cut surface of an apple with an iodine solution spray (2.5 $\mathrm{g} \cdot \mathrm{L}^{-1} \mathrm{I}$ and $10 \mathrm{~g} \cdot \mathrm{L}^{-1}$ potassium iodide in distilled water) for $60 \mathrm{~s}$ and then rating the staining pattern according to the ENZAFRUIT New Zealand International scale from 0 point (cut surface completely clear) to 6 points (cut surface completely stained). Longitudinal quarter sections of fruit were held at $-20{ }^{\circ} \mathrm{C}$ for determination of TA. Titrations were performed according to Harker et al. (2002) by homogenizing $2 \mathrm{~g}$ of tissue from thawed apple sections in $25 \mathrm{~mL}$ distilled $\mathrm{H}_{2} \mathrm{O}$ and titrating the homogenate to an endpoint with a $\mathrm{pH}$ of 8.1 using $0.1 \mathrm{M}$ $\mathrm{NaOH}$. Internal ethylene concentration was determined by injecting a $1-\mathrm{mL}$ core cavity sample into a gas chromatograph (Hewlett Packard, 5890 series II) equipped with an injector at $160{ }^{\circ} \mathrm{C}$, an activated alumina $\mathrm{F} 1$ column (Alltech; glass, $1.5 \mathrm{~m} \times 6 \mathrm{~mm} \times 2$ $\mathrm{mm}$; mesh, 80/100) set isothermally at 130 ${ }^{\circ} \mathrm{C}$, with $\mathrm{N}$ as the carrier gas $\left(20 \mathrm{~mL} \cdot \mathrm{min}^{-1}\right)$, a flame ionization detector set at $200{ }^{\circ} \mathrm{C}(\mathrm{H}$ at $20 \mathrm{~mL} \cdot \mathrm{min}^{-1}$, air at $200 \mathrm{~mL} \cdot \mathrm{min}^{-1}$ ), and an integrator (Hewlett Packard, model 3395) calibrated with certified gas standards.

Controlled atmosphere storage treatment evaluation. 'Pinkie' organic apples were harvested on 14 Mar. 2006 from the HortResearch orchard in Havelock North, New Zealand, and immediately transported to storage facilities at HortResearch, Auckland. 'Pinkie' was selected for this experiment based on several criteria: commercially favorable appearance (pink blush and round shape), early-season production, scab and mildew resistance (Brookfield, 1999), and availability of sufficient fruit numbers from identical conditions in the HortResearch experimental orchard. Previous reports of inadequate storage and shelf life (Brookfield, 1999) were considered impediments to transPacific shipments, but the cultivar had not been evaluated under CA conditions before this study. 
The fruits were sorted into two color categories (low blush, $<20 \%$ blush; moderate blush, $>20 \%$ blush), and a pretreatment evaluation of fruit quality was conducted on a random sample of 20 fruit of each color type using previously described methods. Sixty fruit of each color type were then randomly allocated to three storage treatments at $0.5{ }^{\circ} \mathrm{C}$ : static air ("ambient"), flowthrough air ("control"), and flow-through CA $\left(2.0 \% \mathrm{O}_{2} \pm 0.1 \% ; 1.9 \% \mathrm{CO}_{2} \pm 0.1 \%\right)$. The static fruit were stored in commercial $18.5-\mathrm{kg}$ cardboard cartons, whereas the flow-through treatments were maintained in sealed 20-L plastic containers and supplied with a continuous stream of humidified gas at a flow rate of $200 \mathrm{~mL} \cdot \mathrm{min}^{-1}$. Flow-through treatments were replicated in three separate containers. The $\mathrm{O}_{2}$ and $\mathrm{CO}_{2}$ composition of the headspace in each container was monitored every second day initially, and then weekly thereafter, using a gas analyzer equipped with a miniature infrared $\mathrm{CO}_{2}$ transducer (Analytical Development Company, Hoddeston, UK) in series with an oxygen cell (Citicell C/S type; City Technologies Ltd., London, UK). Fruit were removed after 9 weeks of storage at $0.5{ }^{\circ} \mathrm{C}$. Fruit analyzed after storage were equilibrated overnight to $20{ }^{\circ} \mathrm{C}$ before assessment at 1 and $7 \mathrm{~d}$ of shelf life.

Twenty fruit per replicate were assessed for each storage treatment, skin color category, and shelf life duration. Fruit quality evaluation followed the same protocols as described earlier for the scab-resistant cultivar evaluations, with the addition of background skin color $\left(\mathrm{L}^{*}\right)$ measured with a chromometer (model CR-300; Minolta, Japan), with two readings made per fruit on blush-free areas of skin. The respiration rate of individual fruit was determined as the change in $\mathrm{CO}_{2}$ concentration in the headspace of sealed opaque plastic containers, accounting for sealing time (60 $\mathrm{min})$ and fruit size. Carbon dioxide concentrations were determined by injecting 1-mL samples into a gas analyzer fitted with a miniature infrared $\mathrm{CO}_{2}$ transducer, using $\mathrm{O}_{2}$-free $\mathrm{N}$ as the carrier gas $\left(40 \mathrm{~mL} \cdot \mathrm{min}^{-1}\right)$. Greasiness of apple peel was determined by a tactile measurement and rating system (Brookfield, 1999) of 0 point (no greasy peel), 1 point (slight greasiness), 2 points (moderate greasiness that may affect salability), and 3 points (high greasiness affecting salability).

\section{Benchmarking study of leafroller management and nontarget effects of a spinosad insecticide in New Zealand}

In 2001, 13 organic orchards were organized to serve as "benchmarkers" for the organic apple industry in the Hawke's Bay area (Walker, 2006). Through this program, the orchards were made available for scientific monitoring of insect, disease, tree health, yield, and fruit quality parameters. To test the efficacy of the combined pheromone trapping and organic spray program for 'Braeburn' and 'Royal Gala' organic apples in Hawke's Bay, New Zealand, an experimental method was developed and tested during the 2006 growing season.

Leafroller monitoring. Of the 13 orchards in the organic apple benchmarking study, 10 orchards were selected for leafroller presence on 'Royal Gala' apples and nine were selected for WAA monitoring during the 'Braeburn' harvest (Feb.-Mar. 2006). 'Royal Gala' apples from a minimum of four fieldpacking bins per orchard were monitored as harvests from individual orchard blocks occurred. The variability in bin numbers sampled resulted from varying sizes of orchards; the larger acreage orchards resulted in more apples harvested and bins sampled during the course of the harvest. Apples were individually examined for presence of leafroller by randomly selecting 100 apples/bin and counting apples with the presence of live or dead leafrollers, fresh or old leafroller feeding damage, and other insect pests, such as WAA. Bins were identified according to the number of the leafroller pheromone trap in closest proximity to the block harvested. Total leafroller damage was enumerated by combining all leafroller and leafroller-damaged fruit numbers.

Woolly apple aphid and nontarget effects. Woolly apple aphid was selected as an indicator species to examine the effect of spinosad sprays on nontarget organisms. If the spinosad insecticide was affecting beneficial insects in the orchard system, WAA populations were predicted to increase, because of mortality inflicted by spinosad sprays on WAA natural enemies, particularly European earwig (Forficula auricularia L.) and the parasitic wasp Aphelinus mali (Haldeman).

The extent of natural enemy activity against WAA populations was determined through two methods: monitoring earwig and spider populations in 1-L "milk carton" and cardboard traps (Pawson et al., 1998), and surveys of WAA populations in nine organic orchards. Orchards were clustered according to extent of Entrust use: Five orchards with no Entrust applications and five orchards applying three to four Entrust sprays per season were included in the predator survey. Earwig traps consisted of a $17 \times 45-\mathrm{cm}$ roll of corrugated cardboard inserted inside the empty, plastic milk carton trap, designed to provide a secure location for earwig resting, and the traps were secured with twine against the tree trunk in the middle section of the tree where earwig populations had been observed.
The cardboard traps consisted of a roll of corrugated cardboard stapled around an apple tree limb. There were a total of 12 traps per orchard, sampled biweekly between 3 Mar. and 1 May 2006. Parasitism rates were determined by counting numbers of parasitized WAA individuals ("mummies," or mummified exoskeletons of dead WAA) and total WAA populations on 10 randomly selected water shoots of 10 trees per nine orchards to determine the effect of spinosad on $A$. mali populations.

\section{RESULTS AND DISCUSSION}

\section{Organic apple cultivar evaluation in the midwestern United States}

No scab symptoms developed on 'Gold Rush', 'Enterprise', 'Liberty', and 'Redfree' apples in the organic, grower-managed orchard, demonstrating stable scab resistance when no fungicides were applied. However, at least one S spray during peak scab infection periods is recommended in the event of scab-resistance breakdown (Bus, 1999). Sulfur may also have been effective in reducing quince rust [Gymnosporangium clavipes (Crooke \& Peck)], identified primarily in 'Gold Rush' apples, in which a significantly higher level of symptoms was observed on leaves and on harvested fruit compared with 'Enterprise' and 'Liberty' apples (Table 1). There was an intermediate level of quince rust on 'Redfree' trees (Table 1). Individual fruit weight was greater in 'Enterprise' at $228 \mathrm{~g}$ compared with an average of $148 \mathrm{~g}$ in 'Gold Rush', 'Redfree', and 'Liberty' (Table 1). Nitrogen was not a limiting factor in production, because foliar leaf $\mathrm{N}$ ranged from $2.2 \%$ in 'Enterprise' to $2.3 \%$ in the other three cultivars (data not shown). There were no significant differences among cultivars in plum curculio- and codling moth-damaged apples at harvest (Table 1). Limited incidence of codling moth $(1.8 \%$ to $4.2 \%$ damaged fruits) and plum curculio (3.1\% to $7.1 \%$ damaged fruits) was considered acceptable, because this will result in a $50 \%$ to $100 \%$ price premium at local markets, depending upon availability and season.

The organic spray program was effective in managing codling moth and plum curculio within tolerable levels of less than $10 \%$ damage for direct-market sales. In recent years, however, combinations of mating disruption, $B$. thuringiensis, and codling moth granulosis virus have supplanted kaolin clay

Table 1. Harvest weight and pest pressure on four scab-resistant apple cultivars in a midwestern United States organic demonstration site, 2003-2004.

\begin{tabular}{lccccc}
\hline Cultivars & Fruit $\mathrm{wt}^{\mathrm{z}}(\mathrm{g})$ & $\begin{array}{c}\text { Rust (\% leaves } \\
\text { affected })\end{array}$ & $\begin{array}{c}\text { Codling moth } \\
(\% \text { fruit affected })\end{array}$ & $\begin{array}{c}\text { Plum curculio } \\
(\% \text { fruit affected })\end{array}$ & $\begin{array}{c}\text { Rust (\% fruit } \\
\text { affected) }\end{array}$ \\
\hline Enterprise & $228 \mathrm{a}^{\mathrm{y}}$ & $0 \mathrm{a}$ & 4.2 & 5.3 & $0 \mathrm{a}$ \\
Gold Rush & $139 \mathrm{~b}$ & $40.0 \mathrm{c}$ & 1.8 & 4.0 & $3 \mathrm{~b}$ \\
Liberty & $151 \mathrm{~b}$ & $1.3 \mathrm{a}$ & 3.7 & 7.1 & $0 \mathrm{a}$ \\
Redfree & $154 \mathrm{~b}$ & $18.8 \mathrm{~b}$ & 3.0 & 3.1 & $\overline{-}^{\mathrm{x}}$ \\
LSD $_{0.05}$ & 16 & 8.5 & $\mathrm{NS}$ & $\mathrm{NS}$ & 2.6 \\
\hline
\end{tabular}

${ }^{\mathrm{z}}$ Means averaged over two growing seasons.

${ }^{\mathrm{y}}$ Means followed by the same letter are not significantly different at $P \leq 0.05$.

${ }^{x}$ Data not collected because of insufficient numbers.

${ }^{\text {Ns Nonsignificant. }}$ 
use in many organic apple orchards in the United States and abroad. These results agree with Reganold et al. (2001), who noted that organic apple production systems were competitive and insect pests were managed below economic levels for local markets. In addition, yield and scab-resistance results for 'Liberty' correspond with findings by Ellis et al. (1998) and Merwin et al. (2005).

\section{Evaluation of scab-resistant cultivars at harvest and under controlled atmosphere treatment}

Harvest evaluation. At the first and second harvest dates of this study, the named scab-resistant cultivars, 'Liberty' and 'Pinkie', were smaller fruits, as previously reported (Brookfield, 1999), compared with 'Pacific Rose', a susceptible cultivar, but differences in fruit weight between 'Pinkie' grown under IFP and organic conditions were not significant (Table 2). Apples from the unnamed selections containing scab-resistant genes, called Selection A and Selection B until released, were considerably larger than 'Pinkie' apples, with Selection A significantly larger than 'Pacific Rose' at the first and second harvest dates (Table 2). The Selection B apples were evaluated on different rootstocks, and only on the first harvest date was fruit size on G-202 greater than those on M-9 stock. These new selections were intermediate in size between Selection A and 'Pinkie' apples, with Selection B (G202) the same size as 'Pacific Rose' at the first harvest date, but significantly less at the second harvest date (Table 2). The New Zealand 'Liberty' apples appeared to be smaller than their Iowa counterparts, averaging $125 \mathrm{~g}$ across two harvest dates, compared with $151 \mathrm{~g}$ in Iowa (Table 1).

Ethylene concentrations also did not differ between the organic and IFP 'Pinkie' apples on their first and second harvest dates, but 'Pinkie' IECs were significantly lower than 'Liberty' apples at the second harvest date
(Table 2). Although IEC increased between the first and second harvest dates for all cultivars, IEC differences among cultivars on each harvest date were not significant, with the exception of 'Liberty' apples, which exhibited high IECs from the first harvest date (Table 2). For certain cultivars, however, IEC increase on the tree can occur later than expected, after significant starch clearance (Watkins, 1989), as may be the case with 'Liberty'.

Red color at harvest, measured by the percentage of blush on the apple peel, was higher in 'Liberty' and 'Pacific Rose' apples compared with 'Pinkie', which had a color that is less red at harvest (Table 2). Average blush ratings increased from the first to second harvest date in all cultivars except Selection B on M-9, for which average blush ratings at the second harvest date were lower than on the G-202 rootstock. There was no difference in blush ratings between organic and IFP 'Pinkie' apples on either harvest date. In addition to the excessive size of the Selection A apples, blush ratings were significantly lower than the other cultivars, which may affect acceptance in the marketplace.

Starch indices were not consistently different between organic and IFP apples. There were no differences at the first harvest date, but at the second harvest, the organic 'Pinkie' apples exhibited a higher SPI value than their IFP counterparts (Table 2). The 'Liberty' apples exhibited rapid changes-moving from one of the lowest SPI values of 2.0 at the first harvest date to 4.7 at the second harvest date. 'Pinkie' apples were between 'Liberty' and the unnamed scab-resistant selections showing intermediate ethylene and SPI values as previously reported (Brookfield, 1999). The Selection A apples had one of the lowest SPI ratings at the first and second harvest dates. There were no SPI differences between Selection B apples on either rootstock on both harvest dates, although there was a trend toward higher SPI values on G-202. The scab-resistant cultivars maintained excellent firmness ratings $(>77 \mathrm{~N})$ at the first harvest date, significantly greater than the scab-susceptible cultivar (Table 2). Organic and IFP apples had similar firmness ratings on both harvest dates. 'Liberty' apples were among the firmest apples of the group at the first harvest date, but were not significantly different from all the other scabresistant cultivars at the second harvest date. The susceptible cultivar had the lowest firmness rating on both harvest dates, averaging 59 N. The Selection B apples on G-202 rootstock were firmer than those on M-9 at the second harvest date.

Soluble solids ranged from $12.6 \%$ to $14.3 \%$ at the first harvest date, with lower concentrations in Selection A, organic 'Pinkie', and 'Liberty' apples (Table 2). By the second harvest date, soluble solids concentrations (SSCs) were equivalent in organic and IFP 'Pinkie' apples. Among the highest SSC values obtained was $15 \%$ in Selection B (G-202) at the second harvest date, which was equivalent to 'Pacific Rose' at $14.5 \%$.

Titratable acidity concentration was significantly greater in 'Liberty' and the Selection B apples at the first harvest date compared with the other cultivars (Table 2). At the first harvest date, TA concentrations were greater in organic 'Pinkie' apples but the reverse was observed at the second harvest date when the IFP 'Pinkie' apples had higher TA than the organic 'Pinkie' apples (Table 2). At the second harvest date, 'Pacific Rose' apples exhibited the lowest acidic content and the Selection B apples contained the highest levels. The 'Pinkie' apples had intermediate TA levels at the second harvest date. Taste is a complex balance between sugars and acids, with no clear correlation between high SSC and low malic acid (Harker et al., 2002). Thus, trained and consumer taste panels would be needed to address definitively market acceptance of these new cultivars.

Table 2. Fruit quality comparisons of apple cultivars at harvest, Hawke's Bay, New Zealand, 2006.

\begin{tabular}{|c|c|c|c|c|c|c|c|c|}
\hline Cultivar & Harvest date & Fruit wt (g) & $\begin{array}{c}\mathrm{IEC}^{\mathrm{z}} \\
\left(\mu \mathrm{L} \cdot \mathrm{L}^{-1}\right)\end{array}$ & Blush (\%) & $\begin{array}{l}\text { Starch pattern } \\
\text { index }(1-6 \mathrm{pt})\end{array}$ & $\begin{array}{c}\text { Fruit } \\
\text { firmness }(\mathrm{N})\end{array}$ & $\mathrm{SSC}^{\mathrm{z}}(\%)$ & $\begin{array}{c}\text { Titratable } \\
\text { acidity }(\%)\end{array}$ \\
\hline \multicolumn{9}{|l|}{ Harvest 1} \\
\hline Liberty & 11 Mar. & $115.4 \mathrm{~d}^{\mathrm{y}}$ & 2.58 & $84.1 \mathrm{a}$ & $2.2 \mathrm{~cd}$ & $86.28 \mathrm{a}$ & $13.1 \mathrm{bcd}$ & $0.88 \mathrm{a}$ \\
\hline Pacific Rose & 8 Apr. & $215.9 \mathrm{~b}$ & 0.60 & $87.4 \mathrm{a}$ & $2.8 \mathrm{bc}$ & $64.02 \mathrm{~d}$ & $13.3 \mathrm{bc}$ & $0.28 \mathrm{~d}$ \\
\hline Pinkie, IFPz & 28 Feb. & $129.4 \mathrm{~d}$ & 0.45 & $30.0 \mathrm{c}$ & $3.6 \mathrm{a}$ & $79.41 \mathrm{bc}$ & $13.6 \mathrm{ab}$ & $0.55 \mathrm{c}$ \\
\hline Pinkie, organic ${ }^{z}$ & $28 \mathrm{Feb}$ & $129.3 \mathrm{~d}$ & 0.27 & $34.8 \mathrm{c}$ & $3.2 \mathrm{ab}$ & $81.11 \mathrm{~b}$ & $12.6 \mathrm{~d}$ & $0.59 \mathrm{~b}$ \\
\hline Selection A & $28 \mathrm{Feb}$ & $241.6 \mathrm{a}$ & 0.45 & $0 \mathrm{~d}$ & $1.7 \mathrm{~d}$ & $85.37 \mathrm{a}$ & $12.5 \mathrm{~cd}$ & $0.54 \mathrm{c}$ \\
\hline Selection B-202 & 30 Mar. & $215.1 \mathrm{~b}$ & 1.14 & $82.0 \mathrm{ab}$ & $2.5 \mathrm{bc}$ & $77.05 \mathrm{c}$ & $14.3 \mathrm{a}$ & $0.88 \mathrm{a}$ \\
\hline Selection B-M9 & 30 Mar. & $195.3 \mathrm{c}$ & 0.67 & $74.0 \mathrm{~b}$ & $2.1 \mathrm{~cd}$ & $76.76 \mathrm{c}$ & $14.3 \mathrm{a}$ & $0.88 \mathrm{a}$ \\
\hline $\mathrm{LSD}_{0.05}$ & & 15.6 & NS & 7.81 & 0.65 & 3.58 & 0.69 & 0.02 \\
\hline \multicolumn{9}{|l|}{ Harvest 2} \\
\hline Liberty & 19 Mar. & $133.7 \mathrm{~d}$ & $45.54 \mathrm{a}$ & $89.3 \mathrm{a}$ & $4.7 \mathrm{a}$ & $77.67 \mathrm{~b}$ & $13.5 \mathrm{c}$ & $0.79 \mathrm{~b}$ \\
\hline Pacific Rose & 21 Apr. & $246.2 \mathrm{~b}$ & $1.01 \mathrm{~b}$ & $88.9 \mathrm{a}$ & $3.9 \mathrm{~b}$ & $54.82 \mathrm{c}$ & $14.5 \mathrm{ab}$ & $0.28 \mathrm{f}$ \\
\hline Pinkie, IFP ${ }^{z}$ & 6 Mar. & $134.3 \mathrm{~d}$ & $2.47 \mathrm{~b}$ & $41.5 \mathrm{c}$ & $4.1 \mathrm{~b}$ & $77.08 \mathrm{~b}$ & $13.0 \mathrm{c}$ & $0.63 \mathrm{c}$ \\
\hline Pinkie, organic ${ }^{z}$ & 6 Mar. & $147.0 \mathrm{~d}$ & $4.78 \mathrm{~b}$ & $44.0 \mathrm{c}$ & $4.9 \mathrm{a}$ & $75.61 \mathrm{~b}$ & $13.3 \mathrm{c}$ & $0.59 \mathrm{~d}$ \\
\hline Selection A & 6 Mar. & $265.7 \mathrm{a}$ & $1.08 \mathrm{~b}$ & $22.3 \mathrm{~d}$ & $2.2 \mathrm{~d}$ & $78.06 \mathrm{~b}$ & $13.2 \mathrm{c}$ & $0.45 \mathrm{e}$ \\
\hline Selection B-202 & 6 Apr. & $190.3 \mathrm{c}$ & $2.80 \mathrm{~b}$ & $85.6 \mathrm{a}$ & $2.9 \mathrm{c}$ & $81.98 \mathrm{a}$ & $15.0 \mathrm{a}$ & $0.83 \mathrm{a}$ \\
\hline Selection B-M9 & 6 Apr. & $194.9 \mathrm{c}$ & $1.25 \mathrm{~b}$ & $63.7 \mathrm{~b}$ & $2.7 \mathrm{~cd}$ & $77.18 \mathrm{~b}$ & $14.1 \mathrm{~b}$ & $0.83 \mathrm{a}$ \\
\hline $\mathrm{LSD}_{0.05}$ & & 17.02 & 12.56 & 8.71 & 0.59 & 3.24 & 0.57 & 0.28 \\
\hline
\end{tabular}

${ }^{\mathrm{z} I E C}$, internal ethylene concentration; IFP, integrated fruit production (nonorganophosphate insecticides applied, synthetic fertilizers and synthetic fungicides applied); organic, managed organically (no synthetic fertilizers, no synthetic fungicides, no synthetic insecticides); SSC, soluble solids concentration.

${ }^{\mathrm{y}}$ Means within the first and second harvest dates and between cultivars followed by the same letter are not significantly different at $P \leq 0.05$. 
Results comparing organic and IFP 'Pinkie' fruits correspond with Peck et al. (2006), who found few differences in SSC and TA between organic and IFP apples, and with Wurm and Pieber (2005) who found no differences in TA or apple size between organic and integrated systems. Contrary to results obtained by Weibel et al. (2005), organic 'Pinkie' fruit were not sweeter or firmer than their IFP counterparts. These results also demonstrated that, although 'Pinkie' can be considered an acceptable scabresistant cultivar based on export standards 'Pinkie' background, particularly Selection B on G-202 rootstock, offer the greatest promise for commercially acceptable scab-resistant cultivars.

Controlled atmosphere storage treatment evaluation. Initially, there were no differences in firmness, IEC, or TA concentrations between low-blush ("green") and blushed (D.M. Palmer, 2006), the new selections with

("red") 'Pinkie' fruit before storage (Table 3). The SPI was more advanced in red fruit, but these fruit met export standards (D.M. Palmer, 2006). After CA treatment, CAtreated fruits were firmer than air-stored fruit at 1 and $7 \mathrm{~d}$ of shelf life (Table 4). The CA fruits were 9 to $13 \mathrm{~N}$ firmer than air-stored fruit after 9 weeks at $0.5^{\circ} \mathrm{C}$. Firmness values for $\mathrm{CA}$ fruit met the minimum firmness standards for apples imposed by U.S. export markets $(55$ to $65 \mathrm{~N})$, whereas the air-stored fruit could have been rejected according to these standards. The firmness ratings in the CA-stored fruit were also greater than previously reported for 'Pinkie' stored in air for 4 and 8 weeks (Brookfield, 1999). This beneficial effect of CA on firmness is commercially significant given that texture is an important quality attribute in apples. Although weight loss was also lower in CAstored green fruit compared with air-stored fruit (Table 4), differences were not extensive

Table 3. Organic 'Pinkie' apple fruit quality before controlled atmosphere treatment, Auckland, New Zealand, 2006.

\begin{tabular}{lccc}
\hline & Green $^{\mathrm{y}}$ & Red $^{\mathrm{y}}$ & $P$ value (if $\leq 0.05)$ \\
\hline Fruit weight $(\mathrm{g})$ & $138.4 \mathrm{~b}^{\mathrm{z}}$ & $157.8 \mathrm{a}$ & 0.0058 \\
Lightness & $82.50 \mathrm{a}$ & $81.04 \mathrm{~b}$ & 0.0184 \\
Chroma & $32.19 \mathrm{a}$ & $29.13 \mathrm{~b}$ & 0.0097 \\
Hue $\left({ }^{\circ}\right)$ & $102.10 \mathrm{a}$ & $93.35 \mathrm{~b}$ & 0.0005 \\
Firmness $(\mathrm{N})$ & 70.9 & 69.6 & $\mathrm{NS}$ \\
SSC $(\%)$ & $14.6 \mathrm{a}$ & $13.6 \mathrm{~b}$ & 0.0303 \\
IEC $\left(\mu \mathrm{L} \cdot \mathrm{L}^{-1}\right)$ & 9.97 & 9.10 & NS \\
Titratable acidity $(\%)$ & 0.61 & 0.63 & NS \\
Respiration $\left(\mathrm{nmol} \cdot \mathrm{kg}^{-1} \cdot \mathrm{s}^{-1}\right)$ & $77.7 \mathrm{a}$ & $63.8 \mathrm{~b}$ & 0.0020 \\
SPI $(1-6 \mathrm{pt})$ & $3.55 \mathrm{~b}$ & $4.45 \mathrm{a}$ & $<0.0001$ \\
\hline
\end{tabular}

${ }^{\mathrm{z}}$ Means within each row followed by the same letter are not significantly different at $P \leq 0.05$.

y"Green" designates fruit with a low blush color and "red" designates fruit fully blushed.

${ }^{\text {Ns Nonsignificant. }}$

IEC, internal ethylene concentration; SPI, starch pattern index; SSC, soluble solids concentration. as a result of the use of humidified air in both treatments.

Soluble solids concentrations in fruit from either blush categories were unaffected by the storage atmosphere or shelf life duration (Table 4). When comparing the two blush categories, the soluble solids of green fruit after storage were $\approx 1 \%$ lower than fruit with more blush. The effect of CA on red apples was also noted, because soluble solids increased $\approx 1.5 \%$ after CA treatment. The soluble solids were greater than previously reported for 'Pinkie' apples stored in air (Brookfield, 1999). Results from this study suggest that categorization of fruit by blush may be an effective approach for manipulating the SSC of 'Pinkie' apples in the marketplace. Titratable acidity was generally unaffected by shelf life duration, similar to previous reports (Brookfield, 1999). Red fruit, however, had $0.03 \%$ to $0.05 \%$ higher acidity than green fruit after CA treatments. Bai et al. (2005) have shown that acidity retention under CA treatment is often cultivar dependent, although blush categorization may be equally important.

The IEC of fruit after $1 \mathrm{~d}$ of shelf life was reduced by $\mathrm{CA}$ : Averaging across red and green fruit, there was an $82 \%$ and $85 \%$ lower IEC in CA-stored apples compared with apples in control and ambient conditions, respectively (Table 4). Respiration was also reduced in CA-stored fruit after $1 \mathrm{~d}$ of shelf life, with a $42 \%$ and $52 \%$ lower respiration rate in CA-stored apples compared with apples in control and ambient conditions respectively (Table 4). There was a significant interaction between color and treatment, however, with red fruit tending to have a higher respiration rate than green fruit. After $7 \mathrm{~d}$ of

Table 4. Organic 'Pinkie' apple fruit quality after controlled atmosphere (CA) and air storage, Auckland, New Zealand, 2006.

\begin{tabular}{|c|c|c|c|c|c|c|c|c|c|}
\hline & \multicolumn{3}{|c|}{ Green $^{\mathrm{y}}$} & \multicolumn{3}{|c|}{$\operatorname{Red}^{y}$} & \multicolumn{3}{|c|}{$P$ value $($ if $\leq 0.05)$} \\
\hline & Control & Ambient & CA & Control & Ambient & $\mathrm{CA}$ & Color & Atmosphere & Color $\times$ atmosphere \\
\hline \multicolumn{10}{|c|}{ After CA storage $(9 \mathrm{wk})+1 \mathrm{~d}$ in air } \\
\hline Weight loss (\%) & $0.63 b^{z}$ & - & $0.47 \mathrm{a}$ & $0.46 \mathrm{a}$ & - & $0.43 a$ & $<0.0001$ & $<0.0001$ & 0.0035 \\
\hline Respiration $\left(\mathrm{nmol} \cdot \mathrm{kg}^{-1} \cdot \mathrm{s}^{-1}\right)$ & $87.2 \mathrm{~b}$ & $96.6 b$ & $52.0 \mathrm{c}$ & $88.1 \mathrm{~b}$ & $117.2 \mathrm{a}$ & $50.2 \mathrm{c}$ & 0.0240 & $<0.0001$ & 0.0137 \\
\hline Lightness & $82.34 \mathrm{a}$ & $82.94 \mathrm{a}$ & $81.49 \mathrm{~b}$ & $81.05 \mathrm{~b}$ & $81.64 \mathrm{ab}$ & $79.60 \mathrm{c}$ & $<0.0001$ & $<0.0001$ & NS \\
\hline Chroma & $33.37 \mathrm{bc}$ & $32.24 \mathrm{c}$ & $35.53 \mathrm{a}$ & $34.74 \mathrm{ab}$ & $34.68 \mathrm{abc}$ & $35.28 \mathrm{a}$ & 0.0492 & 0.0163 & NS \\
\hline Hue $\left(^{\circ}\right)$ & $98.10 \mathrm{~b}$ & $98.91 \mathrm{ab}$ & $100.86 \mathrm{a}$ & $94.69 \mathrm{c}$ & $95.57 \mathrm{c}$ & $94.69 \mathrm{c}$ & $<0.0001$ & NS & NS \\
\hline Greasiness $^{\mathrm{x}}(1-3 \mathrm{pt})$ & $1.1 \mathrm{bc}$ & $0.8 \mathrm{c}$ & $0.2 \mathrm{~d}$ & $1.3 \mathrm{a}$ & $1.4 \mathrm{ab}$ & $0.3 d$ & $<0.0001$ & $<0.0001$ & NS \\
\hline Firmness (N) & $52.3 \mathrm{~b}$ & $52.6 \mathrm{~b}$ & $65.5 \mathrm{a}$ & $51.6 b$ & $52.0 \mathrm{~b}$ & $62.9 \mathrm{a}$ & NS & $<0.0001$ & NS \\
\hline SSC $(\%)$ & $13.7 b$ & $13.7 \mathrm{~b}$ & $13.9 \mathrm{~b}$ & $14.8 \mathrm{a}$ & $14.8 \mathrm{a}$ & $15.1 \mathrm{a}$ & $<0.0001$ & NS & NS \\
\hline $\operatorname{IEC}\left(\mu \mathrm{L} \cdot \mathrm{L}^{-1}\right)$ & $68.58 \mathrm{~b}$ & $102.25 \mathrm{a}$ & $15.95 \mathrm{c}$ & $63.12 \mathrm{~b}$ & $85.48 \mathrm{a}$ & $13.05 \mathrm{c}$ & NS & $<0.0001$ & NS \\
\hline TA $(\%)$ & $0.53 b$ & - & $0.57 \mathrm{~b}$ & $0.57 \mathrm{~b}$ & - & $0.62 \mathrm{a}$ & 0.0182 & 0.0058 & NS \\
\hline \multicolumn{10}{|c|}{ After CA storage $(9 w k)+7 \mathrm{~d}$ in air } \\
\hline Weight loss (\%) & $1.70 \mathrm{~b}$ & - & $1.51 \mathrm{a}$ & $1.52 \mathrm{a}$ & - & $1.49 \mathrm{a}$ & NS & 0.0446 & NS \\
\hline Respiration $\left(\mathrm{nmol} \cdot \mathrm{kg}^{-1} \cdot \mathrm{s}^{-1}\right)$ & $88.5 \mathrm{bc}$ & $100.5 \mathrm{a}$ & $87.1 \mathrm{c}$ & $97.5 \mathrm{a}$ & $95.7 \mathrm{ab}$ & $91.4 \mathrm{bc}$ & NS & 0.0103 & NS \\
\hline Lightness & $82.31 \mathrm{ab}$ & $81.85 \mathrm{ab}$ & $82.56 \mathrm{a}$ & $81.73 \mathrm{abc}$ & $81.03 \mathrm{c}$ & $81.55 b c$ & 0.0050 & NS & NS \\
\hline Chroma & $37.14 \mathrm{a}$ & $38.01 \mathrm{a}$ & $34.26 \mathrm{~b}$ & $32.93 b$ & $37.79 \mathrm{a}$ & $34.00 \mathrm{~b}$ & 0.0412 & $<0.0001$ & NS \\
\hline Hue $\left(^{\circ}\right)$ & $95.43 \mathrm{bc}$ & $97.82 \mathrm{a}$ & $95.94 b$ & $92.65 d$ & $95.09 \mathrm{bc}$ & $94.19 \mathrm{~cd}$ & $<0.0001$ & 0.0010 & NS \\
\hline $\operatorname{Greasiness}^{\mathrm{x}}(1-3 \mathrm{pt})$ & $1.7 \mathrm{a}$ & $1.8 \mathrm{a}$ & $0.6 \mathrm{~b}$ & $1.8 \mathrm{a}$ & $2.0 \mathrm{a}$ & $0.7 \mathrm{~b}$ & NS & $<0.0001$ & NS \\
\hline Firmness (N) & $44.6 \mathrm{~b}$ & $44.2 b$ & $53.0 \mathrm{a}$ & $46.9 b$ & $43.1 b$ & $55.9 \mathrm{a}$ & NS & $<0.0001$ & NS \\
\hline $\mathrm{SSC}(\%)$ & $13.9 \mathrm{c}$ & $14.2 \mathrm{bc}$ & $14.3 \mathrm{bc}$ & $14.8 \mathrm{ab}$ & $13.8 \mathrm{c}$ & $15.0 \mathrm{a}$ & 0.02 & 0.02 & NS \\
\hline $\operatorname{IEC}\left(\mu \mathrm{L} \cdot \mathrm{L}^{-1}\right)$ & $99.09 \mathrm{a}$ & $120.60 \mathrm{a}$ & $73.35 \mathrm{bc}$ & $94.70 \mathrm{ab}$ & $116.17 \mathrm{a}$ & $51.39 \mathrm{c}$ & NS & $<0.0001$ & NS \\
\hline TA $(\%)$ & $0.51 b$ & - & $0.54 \mathrm{ab}$ & $0.54 \mathrm{ab}$ & - & $0.57 \mathrm{a}$ & 0.0149 & 0.0244 & NS \\
\hline
\end{tabular}

${ }^{2}$ Means within each row followed by the same letter are not significantly different at $P \leq 0.05$.

" "Green" designates fruit with a low blush color and "red" designates fruit fully blushed.

${ }^{\mathrm{x}}$ Greasiness ratings were based on the following scale: $0 \mathrm{pt}$ (no greasy peel), $1 \mathrm{pt}$ (slight greasiness), $2 \mathrm{pt}$ (moderate greasiness that may affect salability), and $3 \mathrm{pt}$ (high greasiness affecting salability).

${ }^{\text {Ns Nonsignificant. }}$

CA, controlled atmosphere; IEC, internal ethylene concentration; SSC, soluble solids concentration; TA, titratable acidity. 
shelf life, the ethylene concentration increased in both air-stored and CA-stored fruit, but CAstored fruit maintained a $36 \%$ and $48 \%$ lower ethylene concentration than apples in control and ambient conditions, respectively (Table 4). Respiration rate also increased during the $7 \mathrm{~d}$ of shelf life in fruit from the air control and CA storage treatments, but the increase was greater for CA-stored fruit (Table 4). Despite this increase, there was a $6 \%$ and $13 \%$ lower respiration rate in CA-stored fruit compared with control red fruit and ambient green fruit, respectively (Table 4).

Greasiness and background color are important components of skin quality. Greasiness of the fruit peel was reduced under CA, with CA-stored fruit having greasy peel ratings of 0.15 point and 0.32 point in green and red fruit, respectively, compared with 1.07 points and 1.32 points in air-stored fruit (Table 4). This trend continued at $7 \mathrm{~d}$, with CA facilitating a 2.5 to threefold reduction in greasy peel in red and green apples, respectively, compared with apples in air. The background color of fruit with more blush was unaffected by the storage atmosphere or shelf life duration, whereas the skin of low-blush fruit became more yellow (decreased hue) during the shelf life period for all storage treatments. There was also a trend for low-blush fruit to have a greener skin after CA storage than after air storage.

These results correspond with reports from Peck et al. (2006) and Weibel et al. (2005), who noted that organic fruit exhibited high firmness ratings and contained high levels of soluble solids. These results also suggest that CA storage is an effective nonchemical and organic-compliant postharvest technology for maintaining the quality of scab-resistant cultivars such as 'Pinkie'. The short storage life of this cultivar in air may be problematic for countries such as New Zealand that rely on extended storage times to deliver fruit to export markets. Because CA is considered a viable alternative for insect disinfestation (Waddell et al., 1990), CA could also be used to reduce the inherent problem of poor storage potential in scab-resistant cultivars. Further CA trials should be undertaken to optimize the $\mathrm{O}_{2}$ and $\mathrm{CO}_{2}$ concentrations for fruit harvested from different orchards, regions, and seasons, and at different maturities to develop a robust commercial storage protocol that maintains firmness and taste without exacerbating the expression of physiological disorders such as internal browning.

\section{Benchmarking study of leafroller management and nontarget effects of a spinosad insecticide in New Zealand}

Leafroller monitoring. In evaluating leafroller management strategies in organic apple orchards in Hawke's Bay, New Zealand, we determined that $\approx 25 \%$ of all sprays applied to 'Royal Gala', 'Fuji', and 'Braeburn' apples in 2006 were spinosad insecticides (Fig. 1). Other dominant pesticides included pyrethrum, B. thuringiensis, codling moth granulosis virus, and mineral oil. Although

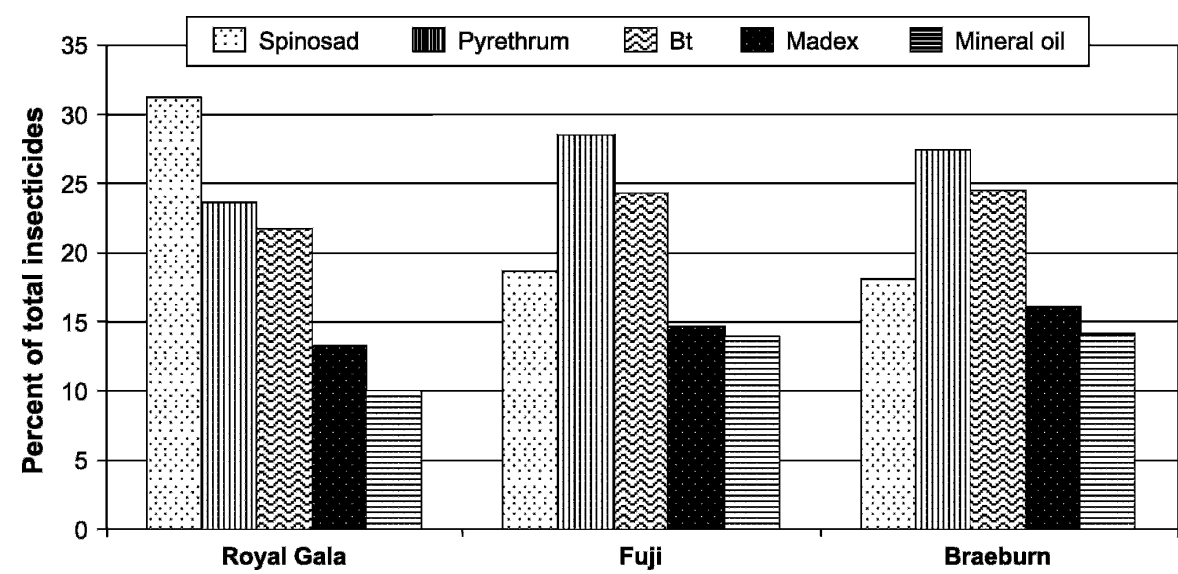

Fig. 1. Types and comparative percentage of insecticide use in organic apple orchards in New Zealand in 2005. Bt, Bacillus thuringiensis; Madex, codling moth granulosis virus.

this insecticide regimen was effective in protecting fruit from codling moth to less than $5 \%$ damage levels (data not shown), leafroller-damaged fruits were observed in packing bins from all orchards surveyed in 2006. Observed leafroller-damaged fruit numbers were low by international organic fruit grower standards (ranging from 5 to 12 damaged apples per 1000 fruit examined), but any incidence of leafrollers or leafroller damage is considered sufficient to reject the entire lot for United States export. The orchard relying on nonspinosad tactics for leafroller control (i.e., only B. thuringiensis) was intermediate in leafroller damage, experiencing an average of nine leafroller damage incidents in 1000 fruit. Adults of leafrollers (LBAM) were monitored through pheromone traps from orchard blocks associated with the specific bins that were examined. These counts ranged from 168 to 522 moths/trap during the course of the survey, with the nonspinosad orchard intermediate in moth catches at 215 moths. Although trap count numbers did not precisely predict the percentage of damaged fruit observed in bins, these traps served as a valuable warning system for the need to increase insecticide applications or prepare for alternative disinfestation at harvest, such as CA treatments, to meet U.S. regulations for export.

Woolly apple aphid and nontarget effects. In evaluating the effect of the spinosad insecticide (Entrust) on beneficial insects (i.e., the parasitic wasp A. mali) and resulting increase in secondary pests, we found an association between increased spinosad use and population increase of the indicator species, WAA, over a 3-month survey of nine organic orchards (Fig. 2A). There was an average of 0.37 WAA colonies/shoot among the four orchards where no spinosad was applied compared with an average of 0.90 WAA colonies/shoot among the five orchards applying an average of 3.2 applications of spinosad (Fig. 2A). With the exception of one of the spinosad-based orchards, where WAA populations were lower than the others, WAA colony size ranged from 140 to $315 / 200$ shoots compared with nonspinosad orchards, where only one orchard had WAA colonies more than 50/200 shoots (Fig. 2A).

Despite the greater WAA population levels in spinosad-based orchards, parasitism rates (putatively by $A$. mali) were also high in these same orchards (Fig. 2B). Parasitism rates averaged $67 \%$ in spinosad-based orchards compared with $92 \%$ in orchards where no spinosad was applied (Fig. 2B). Complete parasitism of all WAA colonies, however, was only observed in orchards where no spinosad was applied (Fig. 2B). The parasitism rates observed in this survey correspond with those previously reported for natural A. mali populations (Walker, 1989) and signify a healthy ecosystem with active biological control. Whether these levels of parasitism are adequate to control WAA to meet California importing regulations of zero WAA tolerance is doubtful, given levels detected in spinosad-based orchards, but other United States and E.U. states with WAA present are more lenient.

Predatory insect population numbers (earwigs and spiders) during the 2-month survey were also associated with spinosad use in 2006 (Fig. 3), where the highest number of earwigs $(n=20)$ and spiders $(n=21)$ was collected in traps from orchards where no spinosad was applied (Fig. 3). However, similar to WAA parasitism rates, predator numbers were high in spinosad-based orchards as well, where overall earwig populations were equal to those in nonspinosad orchards. Thus, beneficial insects appear to be less affected in orchards where spinosad is not applied, but significant beneficial insect communities continue to survive in orchards using spinosad. All organic orchards in the survey had strips of natural and seeded vegetation (e.g., clover) in tree alleyways, which may have assisted in increasing predatory and parasitic species overall (Daly, 1994; Rogers et al., 2003; Wyss, 1995).

The increase in spinosad use may also be correlated to an increase in organic apples permitted access to the United States from 2005 to 2006 . There were $20 \%$ rejected lots in 2005 compared with $14 \%$ in 2006 . After fruits are rejected for U.S. export, marketing 

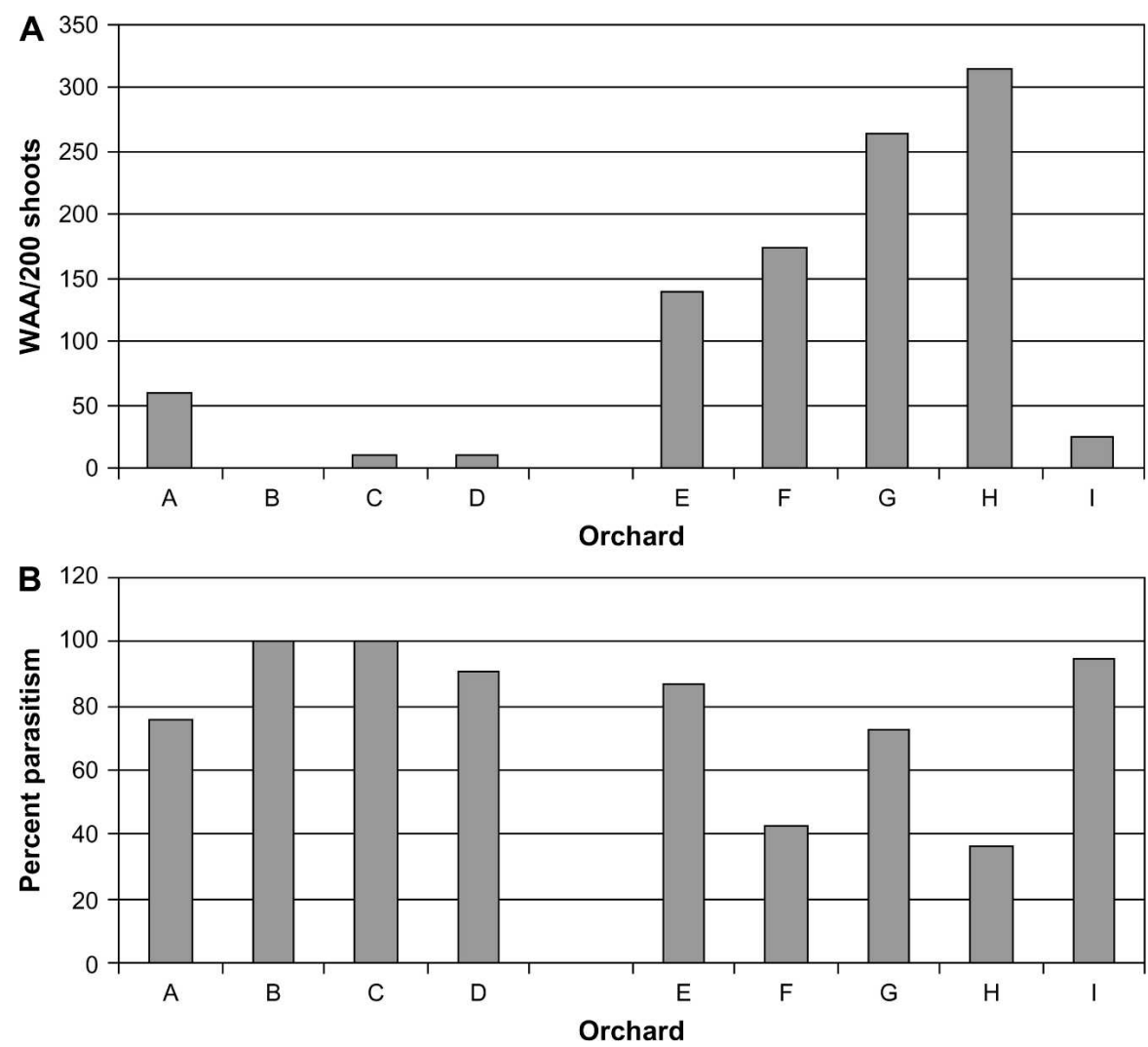

Fig. 2. (A) Woolly apple aphid populations (WAA) in surveyed organic apple orchards in New Zealand, February to May 2006. Orchards A, B, C, and D had no spinosad insecticide used; orchards E, F, G, H, and I had an average spinosad use of 3.2 applications/season. (B) Percentage of parasitized woolly apple aphids in surveyed New Zealand organic apple orchards, February to May 2006. Orchards A, B, $\mathrm{C}$, and D had no spinosad insecticide used; orchards E, F, G, H, and I had an average spinosad use of 3.2 applications/season.

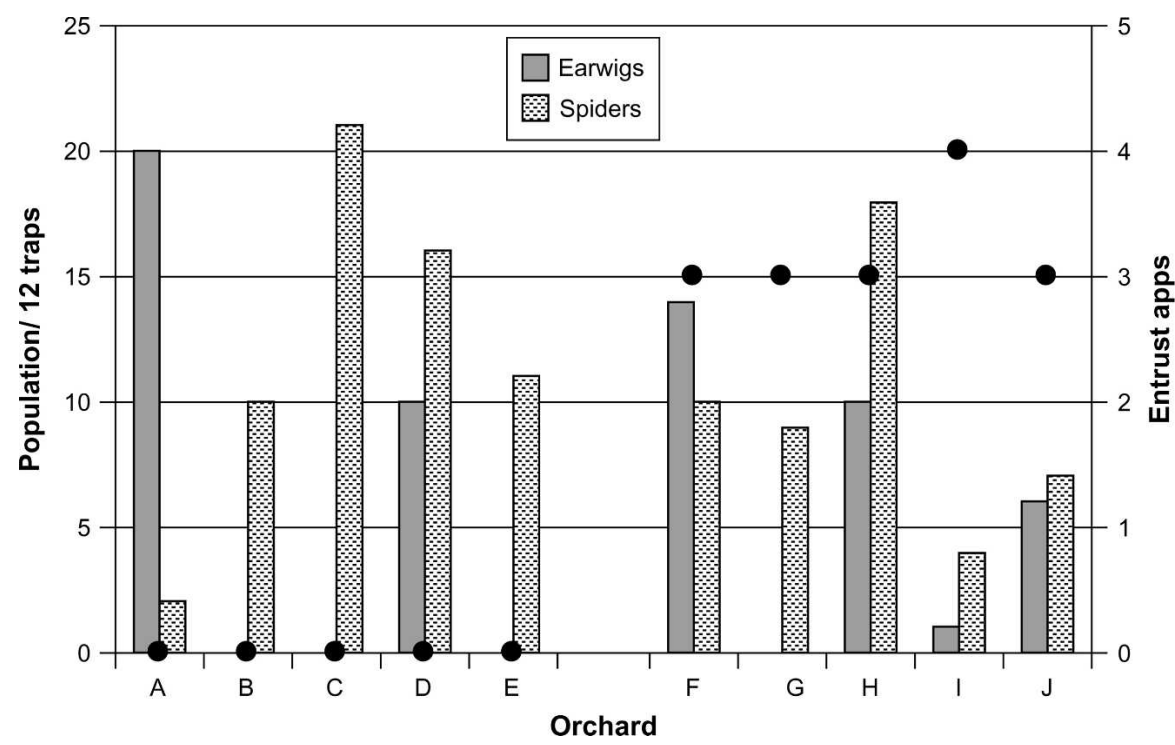

Fig. 3. Numbers of predatory insects (earwigs, dark-gray bars; spiders, light-gray bars) captured in traps on trees in organic apple orchards in New Zealand, Mar. to May 2006. Orchards A, B, C, D, and E had no spinosad insecticide used; orchards F, G, H, I, and J had spinosad used. $\bullet$, number of spinosad applications per season; apps, applications.

options are changed to the EU or local fresh or processing markets. Conversely, if growers expect damaging levels of leafrollers based on trap counts, CA treatments can be used for U.S.-destined fruit in lieu of alternative markets.

\section{CONCLUSIONS}

With global markets for organic products continuing to rise, organic apple producers should be positioned to take advantage of this increasing trend. Organic apple producers using intensive insect and disease management programs have been able to compete with conventional orchards (Delate et al., 2005; Mon and Holland, 2006; Reganold et al., 2001; Roth et al., 2005; Weibel et al., 2004) as a result of the premium prices paid by consumers for the additional costs and perceived benefits of organic production. Smaller fruit size is often cited as a limitation when comparing organic apples with their conventional counterparts, but many consumers have accepted smaller fruit size, particularly in local markets (Ames and Kuepper, 2004).

United States organic apple growers in humid regions have much to gain by following trends in organic production in humid regions of New Zealand, where similar issues include management strategies for apple scab and fruit-feeding insect pests. Additionally, nontarget effects from the increasing use of a more nonspecific, spinosad-based insecticide in both countries warrant cooperative investigations.

Cooperative breeding programs for both scab resistance and fruit quality must be enhanced to address consumer and environmental issues associated with continued sulfur and copper use for scab-susceptible cultivars (Weibel et al., 2003). The absence of scab-infected fruit in the scab-resistant cultivars evaluated in these studies affirms the high level of resistance in these cultivars (Crosby et al., 1992; Wearing et al., 1995b). Despite this resistance, an application of an organic-compliant fungicide during the $\mathrm{Ven}$ turia inequalis ascospore release period will aid in preventing scab-resistance breakdown (Bus, 1999). All scab-resistant cultivars evaluated at harvest in 2006 in New Zealand met quality standards developed by a national organic exporter (D.M. Palmer, 2006), and procedures are underway to test New Zealand cultivars in the United States.

Results of the CA experiment for a scabresistant cultivar with commercial appeal ('Pinkie') were promising in terms of maintaining firmness and SSC ratings within export standards (D.M. Palmer, 2006). The recommendation for marketing small volumes of 'Pinkie' at a time (Brookfield, 1999) may prove to be a successful strategy for local and regional sales. The addition of CATTS (Controlled Atmosphere Temperature Treatment System) (Neven, 2007; Neven and Rehfield-Ray, 2006) to the organic regimen may also allow both increased market access and a longer storage period for scabresistant cultivars.

In addition to apple scab disease management, insect pest management will continue to require innovative strategies for increasingly important pests. Examples include the use of the soil bacteria, Beauvaria bassiana and tillage in tree rows against soil-dwelling larvae of bronze beetle in New Zealand. In the midwestern United States, combination strategies for plum curculio management in organic orchards include the use of pyramid traps baited with attractants and applying $B$. bassiana and steinernemid predatory 
nematodes against beetle larvae, and kaolin clay against adult beetles during egg-laying periods (Whalon, 2006). Current strategies for codling moth management have proved successful in the United States and New Zealand, but quarantined leafrollers remain a challenge for New Zealand organic growers exporting to the United States. Results from research reported here demonstrated greater rates of parasitism of woolly apple aphids in orchards using $B$. thuringiensis alone to manage leafrollers, compared with populations in spinosad-sprayed orchards, but high rates of parasitism were nonetheless recorded in these orchards, signifying an active beneficial insect community in organic orchards. The trade-offs between maintaining a flowering understory for beneficial insects that contribute to reductions in pest populations (Rogers et al., 2003; Solomon et al., 2000) and cover crops supporting pest species, such as leafroller and bronze beetle larvae, needs to be evaluated in light of effects on the entire apple ecosystem and orchard economics. Efficient production of organic apples in humid regions will continue to be challenging in terms of insect and disease management, and marketing options. However, the continued growth in demand for organic products justifies significant efforts to meet these challenges.

\section{Literature Cited}

Ames, G.K. and G. Kuepper. 2004. Overview of organic fruit production. Appropriate technology transfer for rural areas. Fayetteville, AK. 10 Oct. 2006. $<$ http://www.attra.ncat.org/attrapub/fruitover.html $>$.

Bai, J., E. Baldwin, K.L. Goodner, J.P. Mattheis, and J.K. Brecht. 2005. Response of four apple cultivars to 1-methylcyclopropolene treatment and controlled atmosphere. HortScience 40:1534-1538.

Brookfield, P. 1999. Report on 'Pinkie' apple cultivar. HR no: 2000/61. The Horticulture and Food Research Institute of New Zealand, Ltd., Auckland, New Zealand.

Bus, V. 1999. Resistance management with black spot resistant apple cultivars. Technol. Update $1: 40-45$.

Bus, V., A. White, S. Gardiner, R. Weskett, C. Ranatunga, A. Samy, M. Cook, and E. Rikkerink. 2002. An update on apple scab resistance breeding in New Zealand. Acta Hort. 595:43-45.

Campbell, H. and J. Fairweather. 1998. The development of organic horticultural exports in New Zealand. Agribusiness and Economics Research Unit, Lincoln University, Canterbury, New Zealand.

Crawshaw, G. 1997. An overview of the organic industry in New Zealand. The New Zealand Plant Protection Society, Inc., Auckland, New Zealand.

Crosby, J.A., J. Janick, P.C. Pecknold, S.S. Korban, P.A. O'Conner, S.M. Reis, J. Goffreda, and A. Voordeckers. 1992. Breeding apples for scab resistance: 1945-1990. Acta Hort. 317:43-70.

Daly, M.J. 1994. Management techniques for organic apple production in Canterbury, New Zealand. The Horticulture and Food Research Institute of New Zealand, Ltd., Auckland, New Zealand.

Delate, K., J. DeWitt, A. McKern, and R. Turnbull. 2005. Integrated approaches to organic pest management in the Midwestern U.S.A.: Case studies of three crops. Organic Research May 2005: $8 \mathrm{~N}-15 \mathrm{~N}<$ organicresearch.com>.

Delate, K. and H. Friedrich. 2004. Organic apple and grape performance in the Midwestern U.S. Acta Hort. 638:309-320.

D.M. Palmer. 2006. Export pipfruit standards and guidelines-2006. D.M. Palmer New Zealand, Ltd., Hastings, New Zealand.

Dufour, R. 2001. Insect IPM in apples: Kaolin clay. Appropriate technology transfer for rural areas. Fayetteville, AK. 10 Oct. 2006. <http:// www.attra.ncat.org/attra-pub/fruitover.html>.

Ellis, M.A., D.C. Ferree, R.C. Funt, and L.V Madden. 1998. Effects of an apple scab-resistant cultivar on use patterns of inorganic and organic fungicides and economics of disease control. Plant Dis. 8:428-433.

ENZAFRUIT. (New Zealand Apple Fruit Company, Limited). 2007. New Zealand international starch pattern index scale. ENZAFRUIT, Hastings, New Zealand.

Friedrich, H., K. Delate, P. Domoto, G. Nonnecke, and L. Wilson. 2003. Effect of organic pest management practices on apple productivity and apple food safety. Biol. Agr. Hort. 21: $1-14$.

Garcia, M.E., L.P. Berkett, and T. Bradshaw. 2004. First year results of the impact of a novel pest management technology on apple fruit quality. Acta Hort. 638:85-88.

Glenn, D.M., A. Erez, G.J. Puterka, and P. Gundrum. 2003. Particle films affect carbon assimilation and yield in 'Empire' apple. J. Amer. Soc. Hort. Sci. 128:356-362.

Glenn, D.M., G.J. Puterka, T. Vanderzwet, R.E. Byers, and C. Feldhake. 1999. Hydrophobic particle films: A new paradigm for suppression of arthropod pests and plant diseases. J. Econ. Entomol. 92:759-771.

Granatstein, D. 2004. Research directions for organic tree fruit production in North and South America. Acta Hort. 638:369-374.

Harker, F.R., A. Gunson, P.L. Brookfield, and A. White. 2002. An apple a day: The influence of memory on consumer judgment of quality. Food Quality Pref. 13:173-179.

Hughes, J. 2006. Organic apple production update. Agriculture New Zealand, Hastings, New Zealand.

Hughes, J., H. Stiefel, and T. Fraser. 2002. Organic apple production. New Zealand pipfruit technical bulletin no. 004. Agriculture New Zealand, Hastings, New Zealand.

Jamieson, L.E., B.C. Waddell, and P.G. Connolly. 1999. Low temperature treatment for control of quarantine pests: Quick reference guide. Report no. HR98P03.07. The Horticulture and Food Research institute of New Zealand, Ltd., Auckland, New Zealand.

Knight, A.L., T.R. Unruh, B.A. Christianson, G.J. Puterka, and D.M. Glenn. 2000. Effects of a kaolin based particle film on obliquebanded leafroller (Lepidoptera: Tortricidae). J. Econ. Entomol. 93:744-749.

McArtney, S.J. and J.T.S. Walker. 2004. Current situation and future challenges facing the production and marketing of organic fruit in Oceania. Acta Hort. 638:387-396.

Merwin, I., G. Peck, and E. Vollmer. 2005. Organic orchards in the Northeast: Progress, practices and problems, p. 61-62. In: D. Granatstein and A. Azarenko (eds.). Proc. Third National Organic Tree Fruit Res. Symposium. Washington State University Tree Fruit Research and Extension Center, Wenatchee, WA.

Mon, P.N. and D.W. Holland. 2006. Organic apple production in Washington State: An input- output analysis. Renewable Agr. Food Systems 21:134-141.

Neven, L.G. 2008. Organic quarantine treatments for tree fruits. HortScience 43:22-26.

Neven, L.G. and L.M. Rehfield-Ray. 2006. Confirmation and efficacy tests against codling moth, Cydia pomonella, and oriental fruit moth, Grapholitha molesta, in apples using combined heat and controlled atmosphere treatments. J. Econ. Entomol. 99:620-627.

Organic Products Exporters of New Zealand, Ltd. 2006. Organics in New Zealand: 2006. Organic Products Exporters of New Zealand, Inc., Christchurch, New Zealand. 10 Oct. 2006. $<$ http://www.organicsnewzealand.org.nz $>$.

Organic Trade Association. 2005. O.T.A. newsletter. Organic Trade Association, Greenfield, MA.

Pawson, S.M., D.M. Suckling, G.M. Burnip, and A.R. Gibb. 1998. Sampling earwigs in apple orchards. Presented at the Proc. New Zealand Plant Protection Society Symposium, The New Zealand Plant Protection Society, Auckland, New Zealand.

Peck, G.M., P.K. Andrews, J.P. Reganold, and J.K. Fellman. 2006. Apple orchard productivity and fruit quality under organic, conventional, and integrated management. HortScience 41: 99-107.

Puterka, G.J., D.M. Glenn, D.G. Sekutowski, T.R. Unruh, and S.K. Jones. 2000. Progress toward liquid formulations of particle films for insect and disease control in pear. Environ. Entomol. 29:329-339.

Reganold, J.P., J.D. Glover, P.K. Andrews, and H.R. Hinman. 2001. Sustainability of three apple production systems. Nature 410:926930

Rogers, D.J., L.M. Cole, K.M. Delate, and J.T.S. Walker. 2006. Managing bronze beetle, Eucolaspis brunnea, in organic apple orchards. New Zealand Plant Protection 59:1-6.

Rogers, D.J., J.T.S. Walker, I.C. Moen, F. Weibel, P.L. Lo, and L.M. Cole. 2003. Understorey influence on leafroller populations in Hawke's Bay organic apple orchards. New Zealand Plant Protection 56:168-173.

Roth, E., A.Z. Berna, K. Beullens, A. Schenk, J. Lammertyn, and B. Nicolai. 2005. Comparison of taste and aroma of integrated and organic apple fruit. Commun. Agr. Appl. Biol. Sci. 7:225-229.

SAS Institute. 2001. SAS user's guide: Statistics. Version 8.2. Statistical Analysis Service Institute Inc., Cary, NC.

Seagor, M. 2006. Organic statistics. Bio-Gro New Zealand, Ltd., Wellington, New Zealand. 10 Oct. 2006. <http://www.bio-gro.co.nz/>.

Selby, H. and A. White. 1993. Breeding disease resistant apples. Orchardist New Zealand 66:14-16

Solomon, M.G., J.V. Cross, J.D. Fitzgerlad, C.A.M. Campbell, R.L. Jolly, R.W. Olszak, E. Niemczyk, and H. Vogt. 2000. Biocontrol of pests of apples and pears in northern and central Europe: 3. Predators Biocontrol Sci. Technol. 10:91-128.

Statistics New Zealand. 2006. Hectares of land certified as organic by region at 30 June 2002 . New Zealand. 10 Oct. 2006. <http://www.stats. govt.nz/tables/2002-ag-prod/organic-tables.htm>.

Swezey, S.L., P. Vossen, J. Caprile, and W. Bentley. 2000. Organic apple production manual. Publication 3403. University of California, Santa Cruz, CA.

Tamm, L., A. Haseli, J.G. Fuchs, F.P. Weibel, and E. Wyss. 2004. Organic fruit production in humid climates of Europe: Bottlenecks and 
new approaches in disease and pest control. Acta Hort. 638:333-339.

Unruh, T.R., A.L. Knight, J. Upton, D.M. Glenn, and G.J. Puterka. 2000. Particle films for suppression of the codling moth (Lepidoptera: Tortricidae) in apple and pear orchards. J. Econ. Entomol. 93:737-743.

U.S. Department of Agriculture-Agriculture Marketing Service. 2006. National Organic Program. Final rule: 7 CFR part 205. USDA-AMS, Washington, DC, 10 Oct. 2006. <http://www. ams.usda.gov/nop $>$.

U.S. Department of Agriculture-Animal and Plant Health Inspection Service. 2007. USDA confirms light brown apple moth in California: 22 Mar. 2007. USDA-APHIS, Washington, DC, 15 May 2007. <http:// www.aphis.usda.gov/newsroom/content/2007/ 03/applemoth.shtml>.

U.S. Department of Agriculture-Economic Research Service. 2003. Organic production in the U.S. USDA-ERS, Washington, DC. 10 Oct. 2006. <www.ers.usda.gov/data/Organic/>.

Waddell, B.C., P.R. Dentener, and T.A. Batchelor. 1990. Time-mortality response of leafrollers exposed to commercial controlled atmosphere coolstorage, p. 328-333. In: Proc. 43rd Weed and Pest Control Conf.

Walker, J.T.S. 1989. Eriosoma lanigerum (Hausmann), wooly apple aphid (Homoptera: Pemphigidae), p. 197-199. In: P.J. Cameron, R.L. Hill, J. Bain, and W.P. Thomas (eds.). A review of biological control of insect pests and weeds in New Zealand: 1874 to 1987. Technical communication. CAB International Institute of Biological Control 10. CAB International, Wallingford, UK.
Walker, J.T.S. 2006. Organic apple benchmarking study update. The Horticulture and Food Research Institute of New Zealand, Ltd, Havelock North, New Zealand.

Watkins. 1989. Assessment of ethylene production by apple cultivars in relation to commercial harvest dates. N. Z. J. Crop Hort. Sci. 17: 327-333.

Wearing, H., A. O’Brien, and R. Marshall. 1995a. Biological fruit production. The Horticulture and Food Research Institute of New Zealand, Ltd., Auckland, New Zealand.

Wearing, C.H., P.W. Shaw, J.T.S. Walker, R.R. Marshall, and V. White. 1995b. Evaluation of five apple cultivars for their resistance to black spot and powdery mildew in three regions of New Zealand. The New Zealand Plant Protection Society, Inc., Auckland, New Zealand.

Wearing, C.H., J.T.S. Walker, W.P. Thomas, J.R. Clearwater, D.M. Suckling, J.G. Charles, P.W Shaw, V. White, and G.M. Burnip. 1994. Pest control for organic production in New Zealand. The Horticulture and Food Research Institute of New Zealand, Ltd., Auckland, New Zealand.

Weibel, F.P. 2001. Organic fruit production in Switzerland: Research and development to resolve cultural, management, and marketing problems. Amer. J. Alternative Agr. 16:191-195.

Weibel, F.P., A. Haseli, O. Schmid, and H. Willer. 2004. Present status of organic fruit growing in Europe. Acta Hort. 638:375-385.

Weibel, F.P., A. Schmid, and A. Haseli. 2003. Efficient multi-location testing of scab resistant cultivars for organic apple production in Switzerland. Acta Hort. 622:335-342.
Weibel, F.P., D. Treutter, U. Graf, and A. Haseli. 2005. Sensory and health-related fruit quality of organic apples: A comparative field study over three years using conventional and holistic methods to assess fruit quality, p. 185-195. In: Proc. 11th international conference on cultivation technique and phytopathological problems in organic fruit growing, Weinsberg, Germany, 3-5 Feb. 2004.

Whalon, M. 2006. Biopesticides for plum curculio control. Upper Midwest Organic Tree Fruit Network Newsl. 2:1-9.

Whalon, M., J. Flore, J. Biernbaum, G. Bird, R. Perry, J. Scrimger, B. Behe, P. Schwallier, G. Skeltis, L. Gut, S. Smalley, R. Hammerschmidt, G. Sundin, R. Zoppolo, D. Steffanelli, B Wingerd, M. Solomon-Jost, D. Nortman, R. Harwood, G. Byler, D. Ruwersma, A. IrishBrown, J. Smeenk, D. Mutch, T. Dekryger, and B. Gore. 2005. Apple orchard ecosystem management: The organic apple project at the Clarksville, Michigan, horticultural experiment station, p. 35. In: In: D. Granatstein and A. Azarenko (eds.). Proc. Third National Organic Tree Fruit Res. Symposium. Washington State University Tree Fruit Research and Extension Center, Wenatchee, WA.

Wurm, L. and K. Pieber. 2005. Performance test of different apple cultivars in organic and integrated production taking into account different management methods of tree rows. Part 2: Outer fruit quality. Mitt. Klosterneuburg Rebe Wein Obstb. Fruchteverwert. 55:38-56.

Wyss, E. 1995. The effects of weed strips on aphids and aphidophageous predators in an apple orchard. Entomol. Expert. Applicata 75: 43-49. 